\title{
Chemical Characterization of Auriferous Ores from the Brazilian State of Paraiba
}

\author{
Marcelo Rodrigues do Nascimento ${ }^{{ }^{*}}$, Artur M. G. Lourenço² \\ ${ }^{1}$ Instituto Federal de Educação, Ciência e Tecnologia da Paraíba, Laboratório de Flotação, Campina Grande, \\ Brazil \\ ${ }^{2}$ Universidade Federal de Campina Grande, Programa de Pós-Graduação em Engenharia Civil, Campina \\ Grande, Brazil \\ Email: ${ }^{*}$ marceloquimica@gmail.com
}

Received 18 October 2014; revised 20 November 2014; accepted 1 December 2014

Copyright (C) 2015 by authors and Scientific Research Publishing Inc.

This work is licensed under the Creative Commons Attribution International License (CC BY).

http://creativecommons.org/licenses/by/4.0/

(c) (i) Open Access

\section{Abstract}

One of the most important problems facing the gold industry is that the placer and free milling gold ores are almost terminating. Hence, the use of refractory ores has been increased during the recent years. In general, gold refractory ores occurs in various types of deposits associated with a range of minerals. Among the refractory ores, the sulfide type is the most common. The methodology employed in the mining process depends on the mode of occurrence of the ore and on the particle size, shape and degree of purity of the auriferous species. We have undertaken a mineralogical investigation of a representative sample of a complex gold mining ore collected in the municipality of Princesa Isabel, Paraiba, Brazil, using X-ray fluorescence spectrometry, X-ray diffractometry, infrared spectroscopy, inductively coupled plasma-atomic emission spectrometry and the Fire Assay. The results showed that the arsenic content of the ore was closely related to the gold content, and that the occurrence of "invisible gold" was associated primarily with pyrite and secondarily with arsenopyrite. The sulfur content of the ore was directly related to its refractoriness. It is concluded that gold mineralization in the study area is mainly of the gold-quartz-sulfide veins (lode gold), while the gold found in the mini-fractures of the deposits is probably associated with the hydrothermal processes that occurred in the region.

\section{Keywords}

Auriferous Ore, Chemical Characterization, X-Ray Fluorescence Spectrometry, X-Ray Diffractometry, Inductively Coupled Plasma-Atomic Emission Spectrometry

\footnotetext{
${ }^{*}$ Corresponding author.
} 


\section{Introduction}

Although gold is primarily a metal of wealth and commerce, it is also has a wide range of industrial applications in, for example, electronics, biomedicine and space engineering. Gold occurs naturally in the earth's crust but, unlike most metals, it is often found in the native form included in or associated with sulfide matrices, such as pyrite, arsenopyrite, pyrrhotite, and other materials including carbonates, silicates and oxides. Auriferous ores generally contain very low concentrations of the precious metal (1 to $20 \mathrm{ppm}$ ), hence the mining of gold requires complex processes involving sampling, analysis and selective extraction [1]. The specific technologies employed in the mining process depend on the type of gangue associated with the metal and on the particle size, shape and degree of purity of the auriferous species.

Brazil occupies a prominent position in world gold production with the main deposits being concentrated in four different states in the areas known as the Iron Quadrangle in Minas Gerais, Carajás in Pará, Itapicuru and Jacobina in Bahia, and Crixás in Goiás. While the state of Paraíba is not noted for gold production, the Cachoeira de Minas region located in the municipality of Princesa Isabelre presents a significant resource of the precious metal. This area is rich in quartz, limonite, goethite, pyrite, chalcopyrite, galena, sphalerite, covellite, cerussite and arsenopyrite. The gold mainly occurs encased in pyrite crystals, although recrystallized gold is commonly found in the spaces between the quartz crystals, in fissures in quartz andpyrite, and in cavities. Although theamount of gold extracted from ores of Cachoeira de Minas is considered low at $3.65 \mathrm{~g} / \mathrm{ton}$, the yield is comparable with that of some productive mines located in other countries and even in other parts of Brazil where the average gold content in the ores is approximately $2.52 \mathrm{~g} /$ ton [2]. Previous chemical analyses have shown that the amount gold available in auriferous ores shows a wide variation with values ranging from traces up to $34 \mathrm{~g} / \mathrm{ton}$ [3].

In Cachoeira de Minas, gold occurs primarily in auriferous quartz veins, the distinguishing feature of which is the absence or scarcity of hydrothermal alterations in the host rock. In addition, minor occurrences of gold can be found in sulfide-rich shear zones created by hydrothermal alterations where no mining is performed. The distribution of these different zones is determined by the tectonic and metamorphic architecture of the Formação Salinas (distal unit of the Macaúbas Group in the Araçuaí basin). Thus, the gold mineralization in Paraiba is represented mainly by quartz-gold-sulfide veins (lode gold), with primary gold located in rocks of Riacho Gravatá complex. The secondary source is the quartz veins and alluvial deposits, and the gold found in the microfractures of these veins is probably associated with hydrothermal processes that occurred in the area [3].

The aim of the present study was to determine the chemical and mineralogical characteristics of a representative sample of gold mining ore from the municipality of Princesa Isabel (PB, Brazil) in order to evaluate the size distribution, composition and mineral associations of the gold-bearing rock. This quantitative information could be of particular value in gold mining operations for selecting the most cost-effective treatment process, attaining maximum gold recovery, extracting other economically important metals and setting up laboratory testing procedures.

\section{Methodology}

\subsection{Sample Preparation}

Samples of auriferous rock (100 kg) were collected in the region of Princesa Isabel, and subsequently crushed, ground in a disk mill and homogenized in stacks in order to obtain a representative sample of the study area. All transfer operations were carried out using an iron shovel. Screening assays were performed on $1.0 \mathrm{~kg}$ samples using standard Tyler sieves, with mesh openings of 0.600, 0.500, 0.300, 0.177, 0.104 and $0.074 \mathrm{~mm}$, and a vibratory sieve shaker. A precision analytical scale with an accuracy of $1 \mathrm{mg}$ was used to weigh the materials retained by the sieves.

\subsection{Chemical and Mineralogical Analyses}

Samples were subjected to elemental analysis by X-ray fluorescence (XRF) spectrometry employing a RIX3000 instrument (Rigaku, Tokyo, Japan) equipped with a Rh X-ray tube and six analyzing crystals. Crystalline structure was evaluated using a model D-5000 X-ray diffractometer (Siemens, Berlin, Germany) with Cu-Ka as the source of monochromatic radiation. For all samples, scattering intensities were recorded at room temperature over the angular range $2 \theta=10^{\circ}-90^{\circ}$ with a step size of $0.03^{\circ}$ and a step time of $1.0 \mathrm{~s}$. Infrared spectra of sam- 
ples in the form of vacuum-pressed $\mathrm{KBr}$ pellets were measured in the range $4000-400 \mathrm{~cm}^{-1}$ using a Bomem (ABB-Bomem, Quebec, Canada) model MB-102 Fourier-transform infrared (FTIR) spectrometer. Rare earth elements were characterized by inductively coupled plasma-atomic emission spectrometry (ICP-AES) using an ARL model 35,000 instrument (Applied Research Laboratories, Austin, TX, USA). Gold and other noble metals were characterized by the Fire Assay method and atomic absorption spectrometry (AAS) employing an Analyst model 100 spectrometer (Perkin Elmer, Waltham, MA, USA). The limits of detection of the ICP-AES and Fire Assay/AAS techniques were 0.008 - $0.02 \mathrm{ppm}$ for light elements and $0.005 \mathrm{ppm}$ for gold, respectively.

\section{Results}

Particle size classification of the bulk sample (Figure 1) revealed $p_{80}$ and $p_{50}$ values of 0.485 and $0.265 \mathrm{~mm}$, indicating that $80 \%$ and $50 \%$ of the particles, respectively, passed through the 32- and 48-mesh sieves. In addition, $90 \%$ of particles passed through the 28 -mesh sieve, whereas only $14.9 \%$ passed through the 200 -mesh sieve. The mean values of the quantity of material retained in each of the sieves reflect the efficiency of the grinding method since the mechanical properties of the minerals present in the sample are distinct. For example, the host rock is more brittle and has high iron content, whereas the gold-bearing rock (quartz) is very hard.

XRF analysis verified the heterogeneous composition of the sample and confirmed that the levels of silicon dioxide (from the quartz), aluminum oxide and iron oxide were high, as expected (Table 1). The refractoriness of the ore was explained by the presence of arsenic trioxide and sulfur trioxide, which contribute to the difficulty in treating and processing the gold associated with pyrite, arsenopyrite, and chalcopyrite.

ICP-AES analysis (Table 1) revealed that the sample contained various economically important metals such as $\mathrm{Cu}, \mathrm{Zn}$ and $\mathrm{Ni}$ that could be recovered by flotation and/or leaching techniques. The presence of rare earth elements in the ore suggests the possibility of greater exploitation in the longer term, since these materials have a number of applications in the computer industry, industrial engineering, renewable energy sciences and medicine.

According to the Fire Assay/AAS method, the concentration of gold in the ore sample was $4.422 \mathrm{ppm}$ (assay detection limit $0.005 \mathrm{ppm}$ ), a value that is below the limit of detection of XRF (10 ppm or 0.01\%). In this type of mineral ore, the gold is typically dissolved in the interstices, primarily of pyrite and secondarily of arsenopyrite [4].

Since every crystalline material has a specific and characteristic X-ray diffraction pattern, it was possible toidentify the substances present in the sample by comparison of the diffractograms with those published in the literature. The diffraction profile presented in Figure 2 confirms the presence of gold in the study sample [5]-[7], and reveals the face-centered cubic structure of the crystalline material. Additionally, the less intense peak observed at $64.1^{\circ}$ is typical of $\mathrm{Fe}_{2} \mathrm{O}_{3}$ [8].

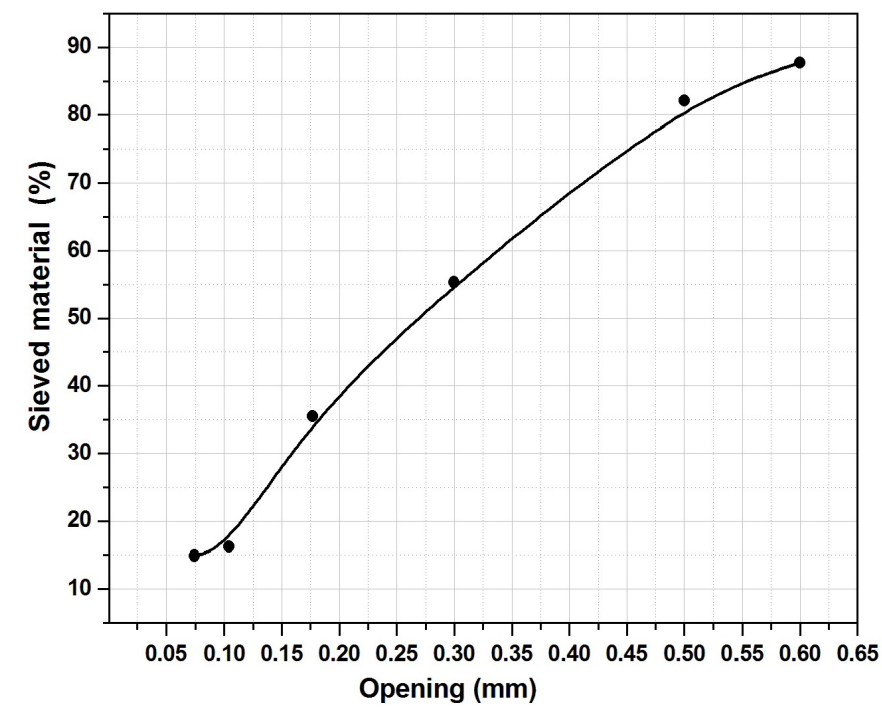

Figure 1. Particle size distribution of a representative sample of gold mining oreoriginating from Princesa Isabel, PB, Brazil. 
Table 1. Chemical profile of a representative sample of gold mining ore originating from Princesa Isabel, PB, Brazil.

\begin{tabular}{|c|c|c|c|c|c|c|c|c|c|c|c|c|}
\hline \multicolumn{13}{|c|}{ Oxides (\%) determined by XRF analysis ${ }^{\mathrm{a}}$} \\
\hline $\mathrm{Al}_{2} \mathrm{O}_{3}$ & $\mathrm{SiO}_{2}$ & $\mathrm{Fe}_{2} \mathrm{O}_{3}$ & $\mathrm{PbO}$ & $\mathrm{SO}_{3}$ & $\mathrm{~K}_{2} \mathrm{O}$ & $\mathrm{MnO}$ & $\mathrm{As}_{2} \mathrm{O}_{3}$ & $\mathrm{TiO}_{2}$ & $\mathrm{CaO}$ & $\mathrm{P}_{2} \mathrm{O}_{5}$ & $\mathrm{MgO}$ & $\mathrm{Cr}_{2} \mathrm{O}_{3}$ \\
\hline 4.55 & 66.81 & 17.42 & 2.41 & 3.08 & 1.33 & 0.56 & 0.27 & 0.23 & 0.19 & 0.20 & 0.10 & 0.10 \\
\hline \multicolumn{13}{|c|}{ Metals (ppm) determined by Fire Assay/AAS and ICP-AES analysis } \\
\hline $\mathrm{Zn}$ & $\mathrm{Zr}$ & $\mathrm{V}$ & $\mathrm{Cu}$ & Mo & $\mathrm{Ni}$ & $\mathrm{Rb}$ & $\mathrm{Tl}$ & $\mathrm{Zn}$ & $\mathrm{Sr}$ & $\mathrm{Ba}$ & $\mathrm{Au}$ & \\
\hline 194 & 27 & 71 & 280 & 40 & 82 & 25 & 25 & 194 & 75 & 195 & 4.42 & \\
\hline \multicolumn{13}{|c|}{ Rare earth elements (ppm) determined by ICP-AES analysis } \\
\hline Ce & Gd & Hf & $\mathrm{La}$ & $\mathrm{Nd}$ & $\operatorname{Pr}$ & Sm & $\mathrm{U}$ & $\mathrm{Yb}$ & & & & \\
\hline 18 & 1.45 & 1.32 & 9.50 & 7.90 & 2.21 & 1.10 & 1.10 & 0.90 & & & & \\
\hline
\end{tabular}

${ }^{\mathrm{a}}$ Loss on Ignition $(\mathrm{LOI})=2.52 \%$.

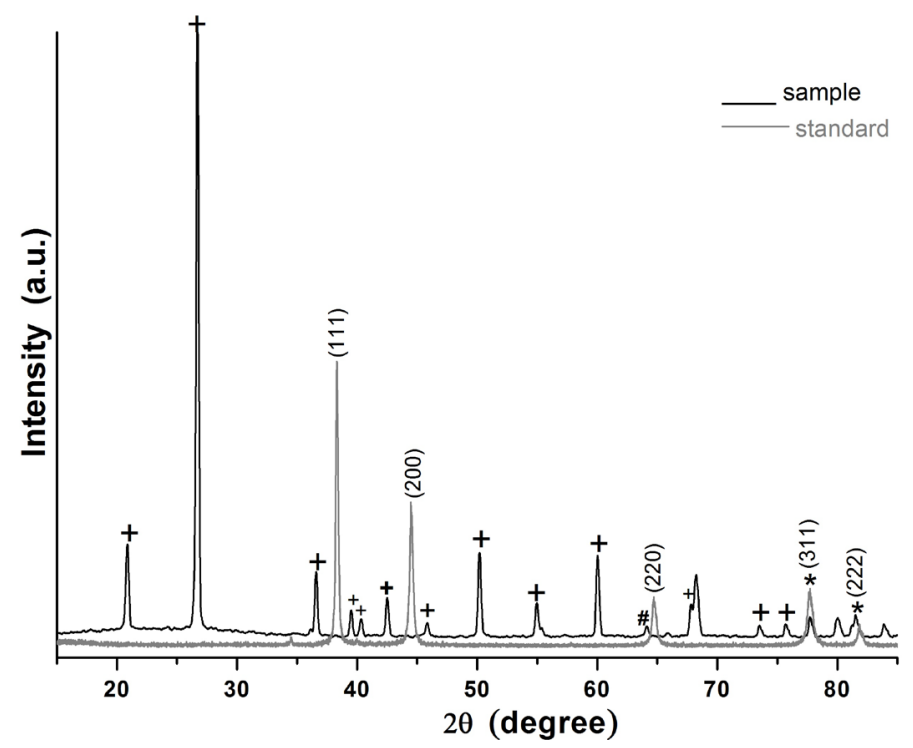

Figure 2. X-ray diffraction profile of a representative sample of gold mining ore originating from Princesa Isabel, PB, Brazil. Legend: Au $(*) ; \mathrm{SiO}_{2}(+) ; \mathrm{Fe}_{2} \mathrm{O}_{3}(\#)$.

Information regarding the $\mathrm{SiO}_{2}$ matrix could be obtained from the FTIR spectrum (Figure 3). Based on detailed interpretations of the IR spectra of various silica-containing structures [9]-[11], a band attributable to the asymmetric stretching mode of Si-O bonds in an $\left[\mathrm{SiO}_{4}\right]^{2-}$ tetrahedron was observed around $1080 \mathrm{~cm}^{-1}$. Although this band could be overlapping with another band corresponding to $\gamma-\mathrm{Al}_{2} \mathrm{O}_{3}$ [12], the symmetric stretching modes of Si-O bonds could be readily observed at around $785 \mathrm{~cm}^{-1}$, and bands between 565 and $455 \mathrm{~cm}^{-1}$ could be assigned to the deformation vibrations of Si-O-Si bonds.

\section{Discussion}

In the recovery of gold from auriferous rock, the particle size at which the metal lies represents a key factor in determining the overall efficiency of the process. In this context, the crushing and grinding steps are extremely important since they determine the range of particle sizes generated from the ores. According to the literature [3], $80 \%$ of gold can be collected on sieves ranging between 100 and 400 mesh. Hence, the aim of a particle sizestudy is to establish sieve sizes that allow the selection of particles with a high degree of release, thereby facilitating the separation of particles of interest from the gangue. Although ball mills are normally employed in grinding in gold mining operations [13], a disk mill was used in the present study because the sample rocks ex- 


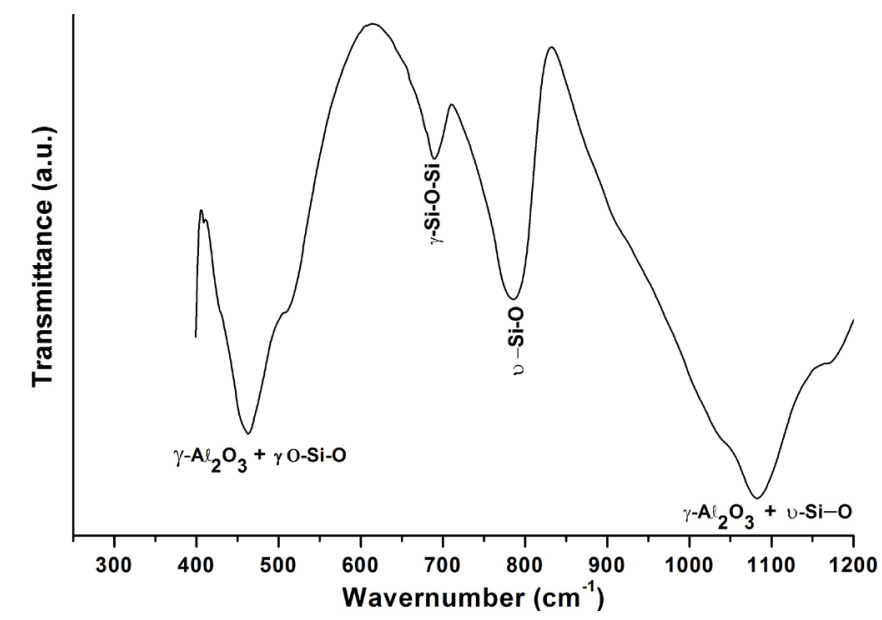

Figure 3. Fourier-Transform infrared spectrum of a representative sample of gold mining ore originating from Princesa Isabel, PB, Brazil.

hibited elevated hardness owing to the presence of quartz.

It may be inferred from the results presented herein that the gold in ores from the state of Paraiba is associated predominantly with pyrite, arsenopyrite and sulfide. Refractory ores of this type generally require treatment involving roasting, bacterial oxidation or fine grinding. The mechanism of incorporation of submicroscopic particles of gold into sulfides has not yet been elucidated, but it has been suggested that gold is assimilated as sulfide by chemisorption onto surfaces that are Fe-deficient and As-rich, where it exists as a metastable solid solution [14]. Simon et al. [15] demonstrated that gold was present in the structure of arsenopyrite as microinclusions of $\mathrm{Au}^{0}$ and $\mathrm{Au}^{1+}$, while $\mathrm{Au}^{0}$ concentrated in fine pyrite at lower temperatures. Cabri et al. [16] confirmed that gold is present in arsenopyrite either as microparticles of $\mathrm{Au}^{0}$ or in the form of covalently linked $\mathrm{Au}^{1+}$. These ores can become more reactive if the crystal lattice energy is reduced, and this can be achieved through mechanical grinding and/or vibration techniques. In this case, the reduction of the activation energy of the reaction is attributed to microcracks and structural defects.

In the last decade, numerous studies have been performed with the purpose of augmenting gold recovery and developing cleaner technologies, but few studies have focused on understanding the mineralogy of the deposits in which gold can be found. Knowledge of the composition of the rocks that encase the precious metal can contribute to the reduction in operational and production costs. In this context, our study provides essential data regarding a representative sample of auriferous ore from the state of Paraiba.

\section{Conclusion}

It is concluded that the submicroscopic gold particles incorporated into the crystal lattice of pyrite and arsenopyrite are progressive released as inclusions and fractures, and the presence of such particles is the main factor responsible for the refractoriness of the auriferous ore from Princesa Isabel, PB, Brazil. This information is of considerable importance since, in ores containing pyrite and arsenopyrite, the fine particles of gold are occluded and disseminated among the sulfide minerals and cannot be released solely by mechanical grinding. The flotation concentrates of this type of gold ore are usually pre-treated by pyrometallurgical or hydrometallurgical methods.

\section{Acknowledgements}

The authors wish to thank the Conselho Nacional de Desenvolvimento Científico e Tecnológico (CNPq; grant no. 550261/2010-9) for financial support and the miners from Princesa Isabel for assistance with sample collection.

\section{References}

[1] Ojeda, M.W., Perino, E. and Ruiz, M.C. (2009) Gold Extraction by Chlorination Using a Pyrometallurgical Process. 
Minerals Engineering, 22, 409-411. http://dx.doi.org/10.1016/j.mineng.2008.09.002

[2] Barbosa, J.S.F. and Sabaté, P. (2004) Archean and Paleoproterozoic Crust of the São Francisco Craton, Bahia, Brazil: Geodynamic Features. Precambrian Research, 133, 1-27.

[3] La Brooy, S.R., Linge, H.G. and Walker, G.S. (1994) Review of Gold Extraction from Ores. Minerals Engineering, 7, 1213-1241. http://dx.doi.org/10.1016/0892-6875(94)90114-7

[4] Celep, O., Alp, İ., Deveci, H. and Vicil, M. (2009) Characterization of Refractory Behavior of Complex Gold/Silver Ore by Diagnostic Leaching. Transactions of Nonferrous Metals Society of China, 19, 707-713. http://dx.doi.org/10.1016/S1003-6326(08)60337-4

[5] Suh, I.-K., Ohta, H. and Waseda, Y. (1988) High-Temperature Thermal Expansion of Six Metallic Elements Measured by Dilatation Method and X-Ray Diffraction. Journal of Materials Science, 23, 757-760. http://dx.doi.org/10.1007/BF01174717

[6] Owen, E.A. and Yates, E.L. (1933) Precision Measurements of Crystal Parameters. Philosophical Magazine, 15, 472488. http://dx.doi.org/10.1080/14786443309462199

[7] Jette, E.R. and Foote, F. (1935) Precision Determination of Lattice Constants. Journal of Chemical Physics, 3, 605616.

[8] Longati, A.A., Ferreira, W.C., Quintão, C.M.F., Maloncy, M.L. and Batista, M.S. (2014)Conversão Química de NO e CO Sobre Catalisadores à Base de Óxidos de Cobalto ou de Ferro.Química Nova, 37, 221-225.

[9] Kawano, Y., Denofre, S. and Gushikem, Y. (1994) Raman and Infrared Spectra of Silica Gel and Niobium (V) Oxide Grafted on Silica Gel Surface and Their Dependence on Pretreatment Temperatures. Vibrational Spectroscopy, 7, 293302. http://dx.doi.org/10.1016/0924-2031(94)85019-4

[10] Pinto, A.C., Braga, W.F., Rezende, C.M., Garrido, F.M.S., Veiga, V.F., Bergter, L., Patitucci, M.L. and Antunes, O.A.C. (2000) Separation of Acid Diterpenes of Copaifera cearensis Huber ex Duckeby Flash Chromatography Using Potassium Hydroxide Impregnated Silica Gel. Journal of the Brazilian Chemical Society, 11, 355-360. http://dx.doi.org/10.1590/S0103-50532000000400005

[11] d'Azevedo, C.A., Garrido, F.M.S. and Medeiros, M.E. (2006) The Effect of Mechanochemical Activation on the Reactivity in the $\mathrm{MgO}-\mathrm{Al}_{2} \mathrm{O}_{3}-\mathrm{SiO}_{2}$ System. Journal of Thermal Analysis and Calorimetry, 83, 649-655. http://dx.doi.org/10.1007/s10973-005-7405-1

[12] van der Marel, H.W. and Beutelspacher, H. (1976) Atlas of Infrared Spectroscopy of Clay Minerals and Their Admixtures. Elsevier, Amsterdam.

[13] Chen, T.T., Cabri, L.J. and Dutrizac, J.E. (2002) Characterizing Gold in Refractory Sulfide Gold Ores and Residues. The Journal of the Minerals, Metals and Materials Society, 54, 20-22. http://dx.doi.org/10.1007/BF02709181

[14] Fleet, M.E., Chryssoulis, S.L., MacLean, P.J., Davidson, R. and Weisener, C.G. (1993) Arsenian Pyrite from Gold Deposits: Au and As Distribution Investigated by SIMS and EMP, and Color Staining and Surface Oxidation by XPS and LIMS. The Canadian Mineralogist, 31, 1-17.

[15] Simon, G., Huang, H., Penner-Hahn, J.E., Kesler, S.E. and Kao, L.-S. (1999) Oxidation State of Gold and Arsenic in GoldBearing Arsenian Pyrite. American Mineralogist, 84, 1071-1079.

[16] Cabri, L.J., Newville, M., Gordon, R.A., Crozier, E.D., Sutton, S.R., McMahon, G. and De-Tong, J. (2000) Chemical Speciation of Gold in Arsenopyrite. The Canadian Mineralogist, 38, 1265-1281. http://dx.doi.org/10.2113/gscanmin.38.5.1265 
Scientific Research Publishing (SCIRP) is one of the largest Open Access journal publishers. It is currently publishing more than 200 open access, online, peer-reviewed journals covering a wide range of academic disciplines. SCIRP serves the worldwide academic communities and contributes to the progress and application of science with its publication.

Other selected journals from SCIRP are listed as below. Submit your manuscript to us via either submit@scirp.org or Online Submission Portal.
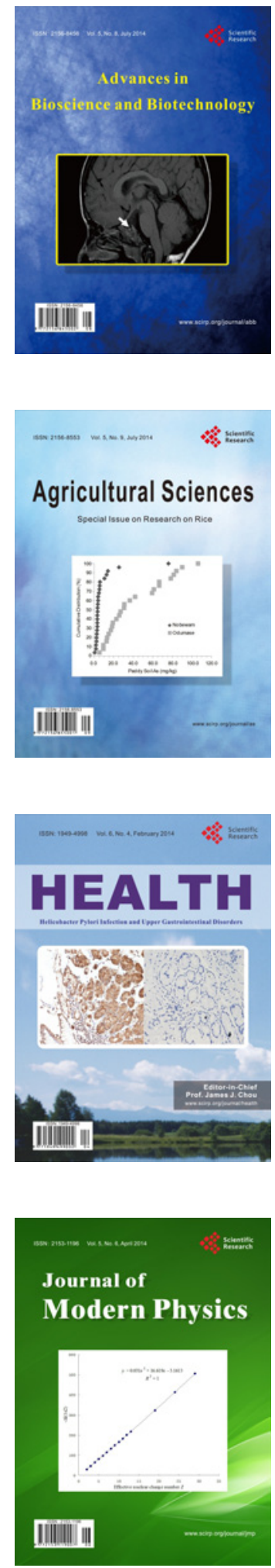
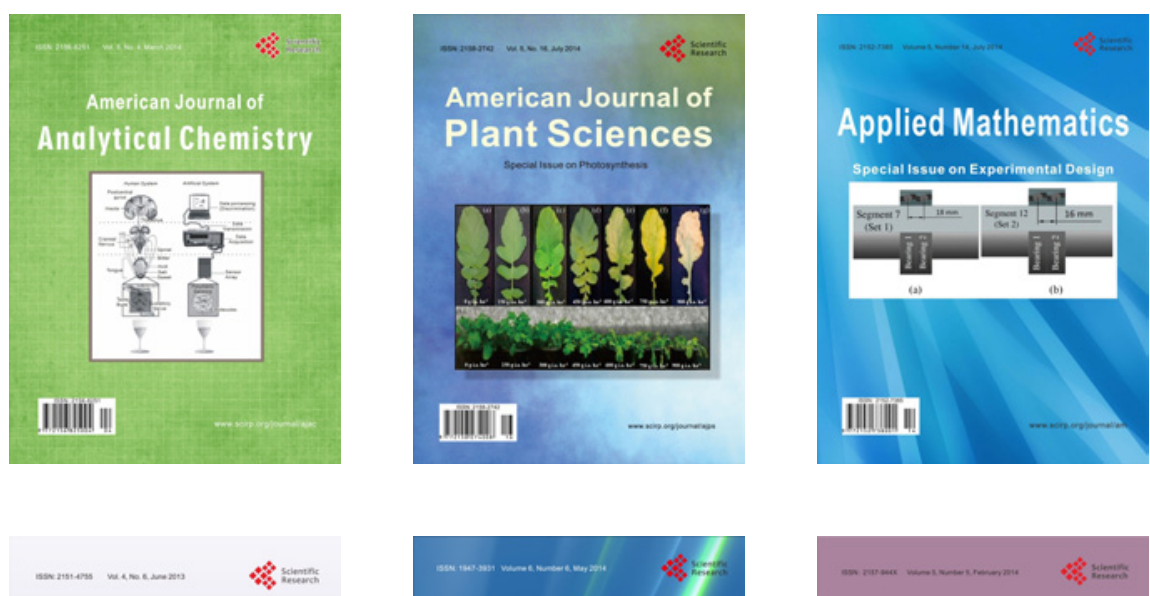

Creative Education
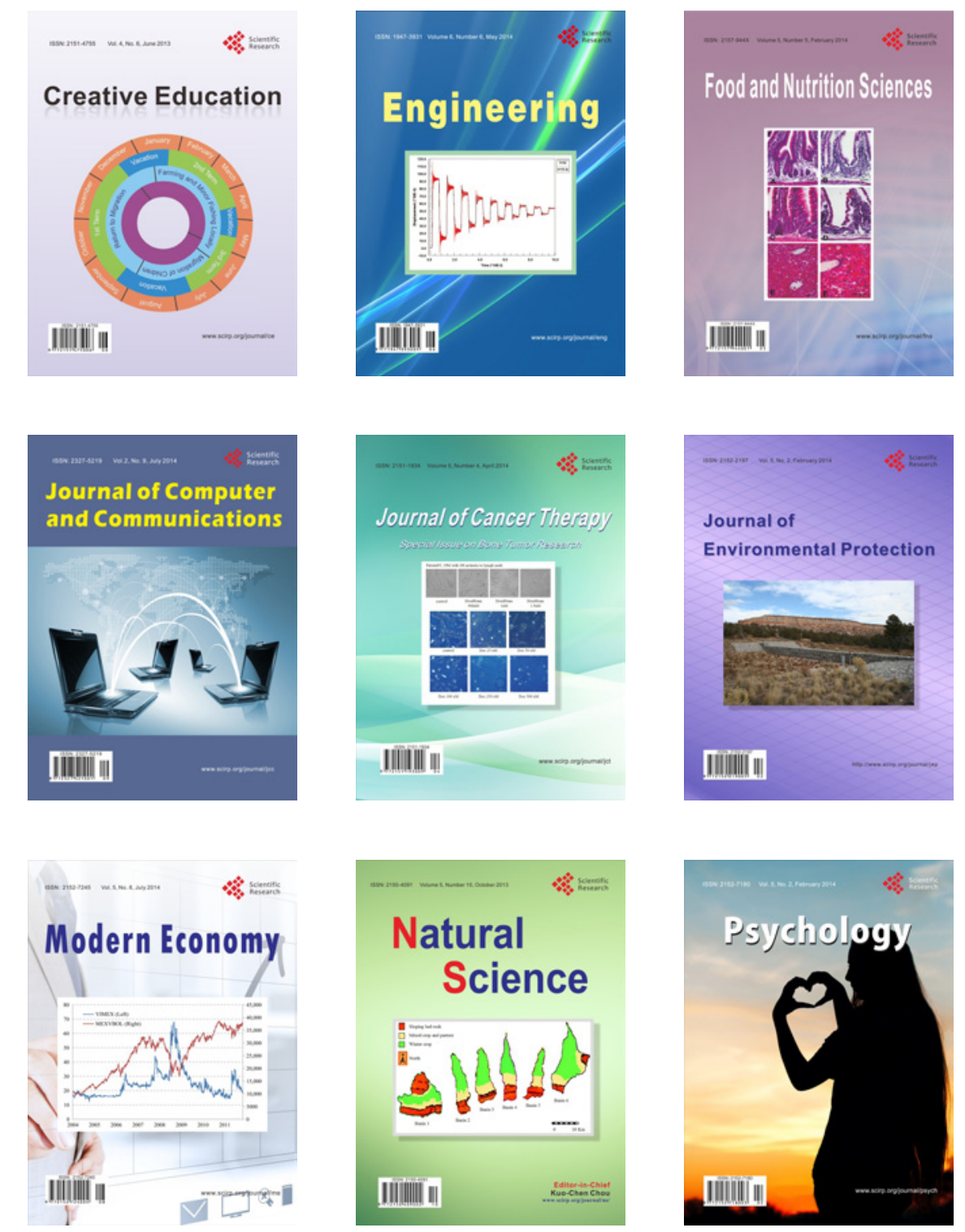